\title{
ДО ПИТАННЯ ЗАРОБІТНОЇ ПЛАТИ КЕРІВНИКІВ СИСТЕМИ ОХОРОНИ ЗДОРОВ'Я
}

\author{
Тернопільський національний медичний університет \\ імені І. Я. Горбачевського МОЗ України, м. Тернопіль, Україна
}

\begin{abstract}
Мета: обґрунтувати концептуальні напрями формування заробітної плати керівників системи охорони здоров'я.
Матеріали і методи. Для досягнення поставленої мети у роботі застосовували загальнонаукові методи аналізу, синтезу, узагальнення, інтерпретації наукових даних, а також системний і структурно-срункціональний підходи.

Результати. Концептуальні напрями формування заробітної плати керівників системи охорони здоров'я обґрунтовано з урахуванням системного підходу, Конституції України, законів та інших нормативно-правових актів України, загальновизнаних принципів і норм міжнародного права у галузі охорони здоров'я, вітчизняного i зарубіжного досвіду. Концептуальні напрями утворюють нову систему формування заробітної плати на принципах державно-приватного партнерства, забезпечують стійкий економічний стан і можливість розвитку бази медичного закладу.

Висновки. Розробка концептуальних напрямів формування заробітної плати керівників системи охорони здоров'я дозволить оптимізувати роботу медичного закладу та забезпечить неухильний розвиток закладу шляхом надання високоякісних медичних послуг, використовуючи при цьому мінімальні витрати ресурсів та запроваджуючи інновації науково-технічного прогресу.
\end{abstract}

КЛЮЧОВІ СЛОВА: заробітна плата; система охорони здоров'я; керівник; посадовий оклад.

Зміни до діючого законодавства щодо оплати праці керівникам закладів охорони здоров'я, які пропонує МОЗ України, орієнтовані в основному на досягнення соціальної справедливості. Суть зводиться до того, щоб обмежити доходи керівників і винайти обмеження їх збагаченню, прив'язавши їх доходи до доходів лікарів.

Питання оплати праці дуже складне і повинно враховувати дуже багато чинників, починаючи із урахування кваліфрікації працюючого, а це затрати на його підготовку, іншими словами - певна «собівартість» фрахівця, це енергетичні та часові витрати його праці, це психологічна складова, це відповідальність, це складність самої праці, це мотиваційна складова тощо. На жаль, все перелічене не має ніякого стосунку до визначення оплати праці сучасного лікаря. Ці сумні реалії 3 прив'язки заробітної плати лікаря до низького коефріцієнта тарифної сітки або до фонду виділених НСЗУ коштів не мають оптимістичного майбутнього. То ж у такому ракурсі заробітна плата керівника закладу охорони здоров'я у 160 тис. грн дійсно виглядає необґрунтовано. Але, якщо подивитись на його зарплату через призму порівняння із заробітними платами керівників державних підприємств, не кажучи про приватні структури, коли розмір посадового окладу керівників «Укргазвидобування» становить до півмільйона гривень, то ситуація виглядатиме дещо іншою.

Виникає питання, який чинник вважати вихідним при визначенні оплати праці керівника. Маючи важелі впливу на людські та матеріальні ресурси організації, керівник, у більшості випадків,

(с) О. Н. Литвинова, Л. В. Ліштаба, 2021 буде працювати у такому напрямку, який принесе йому найбільші дивіденди. Саме тому організація праці має бути вибудована так, щоб його прагнення до зростання власного добробуту було орієнтоване на забезпечення відповідного розвитку організації, якою він керує. Чим вищий рівень розвитку організації - тим вищі доходи керівника. Залишається лише визначитися 3 показниками діяльності організації та критеріями їх оцінки. 3 маркетинговими структурами дещо простіше: чим більший обсяг реалізації продукції - тим вищі доходи керівництва. Тут чудово працює ланцюгова реакція, коли керівник напряму зацікавлений у збільшенні доходів своєї підлеглої команди, бо його заробіток кратний їхнім досягненням. У системі медичної допомоги такий підхід хибний і негуманний. Не можемо ж ми платити лікарям за кількість наданих послуг і стимулювати керівника ці послуги збільшувати. Не може заклад охорони здоров'я прагнути до збільшення кількості пацієнтів та нарощувати обсяги наданих медичних послуг. Презумпція здоров'я це мета держави, а не процвітання медичних закладів за рахунок хворих.

Мета роботи: обґрунтувати концептуальні напрями формування заробітної плати керівників системи охорони здоров'я.

Матеріали і методи. Для досягнення поставленої мети у роботі застосовували загальнонаукові методи аналізу, синтезу, узагальнення, інтерпретації наукових даних, а також системний і структурно-фрункціональний підходи.

Результати дослідження та їх обговорення. Як же виглядає сьогодні система призначення 
окладу керівнику закладу охорони здоров'я КНП? Варто звернути увагу на той фракт, що при отриманні статусу комерційного неприбуткового підприємства заклад отримав певну свободу в призначенні окладів усіх працівників, у тому числі керівникові [1]. Такі фрінансові вольності дозволяють як довільне призначення окладів, так і користування старими нормами єдиної тарифної сітки. Вибір за колективом і визначені умови обов'язково фріксуються у трудовому договорі.

Що ж до оплати праці керівників, то певний вибір стратегії теж залишається, хоч певні умови прописані у чинному законодавстві.

Відповідно до Закону України «Про оплату праці», механізм нарахування зарплати керівникам установ державної та комунальної фрорми власності підлягає державному регулюванню шляхом обговорення цих умов у контракті з власниками закладу [3].

В основі зарплати керівника лежить його посадовий оклад. Оклад директора КНП визначає Постанова Кабінету Міністрів України від 19 травня 1999 р. № 859 [8]. Його розмір залежить від мінімального окладу в закладі для медпрацівника, а також від обсягів господарської діяльності підприємства, зокрема й чисельності працівників. Зазвичай заклади охорони здоров'я - КНП мають менше 500 осіб, тому норма для визначення окладу керівника буде становити 10 мінімальних посадових окладів у медичному закладі працівника основної професії (або виконуються економічні показники: виручка (чистий дохід) менша 200 млн грн, а вартість активів - менше 1 млрд грн). На той час мінімальний посадовий оклад був оклад медичної сестри за тарифрним розрядом, який за 2020 р. становив 3764 грн. Отож, оклад керівника такого закладу становитиме 37640 грн.

Ця ж Постанова передбачає виплату премій керівникові, якщо у закладі, яким він керує, немає ні заборгованості із заробітної плати працівникам, ні боргів за комунальні платежі чи інші платежі до державного/місцевих бюджетів. Розміри цих премій прив'язані до посадового окладу керівника. Щоквартальна премія становить три посадові оклади (у нашому випадку це $37640 \times 3$ $\times 4=451680$ грн). Окрім того, в кінці року за тих же умов керівник отримує ще премію у 24 посадові оклади (37 $640 \times 24=903360$ грн). За ефрективне управління державним майном керівникові в кінці року ще нараховують 6 посадових окладів (37 $640 \times 6=225840$ грн). Таким чином, сумарний річний дохід керівника закладу охорони здоров'я - КНП, при його адекватній діяльності, сягає $451680+451680+903360+225840=$ 2032560 грн (169 380 грн/міс.).

Тут варто зауважити, що, відповідно до даної Постанови, оклади, премії та інші частини зарплати не можуть виходити за межі затвердженого фонду оплати праці (фінансовий план КНП затверджують в управлінні комунальним майном місцевої ради). Тому трапляються випадки, коли керівник закладу охорони здоров'я не включає у колективний договір надбавки і доплати окремим категоріям медиків, які прописані у нормативних актах, що поширюються на бюджетні установи. Таким чином, закон ніби не порушується, бо заклад охорони здоров'я не є бюджетною установою і фонд оплати економиться, суд такий договір недійсним не визнає, і йому на премії вистачить...

Також потрібно врахувати, що даний законодавчий акт не передбачає доплати за звичайний медичний стаж, проте уможливлює доплати за науковий стаж та наукові звання, які становлять: кандидат наук - $15 \%$, доктор наук - $20 \%$, вчене звання доцента (або старшого наукового співробітника) - $25 \%$, вчене звання профресора - $33 \%$ Таким чином, якби наш респондент був доктором медичних наук і професором - його посадовий оклад був би 57589 грн, а сумарний річний дохід із урахуванням премій та доплат = 3109806 грн (259 150,5 грн/міс.).

Враховуючи такі великі розбіжності у заробітній платі керівників та медичних працівників закладів охорони здоров'я, Міністерство охорони здоров'я України запропонувало для громадського обговорення проект Постанови Кабінету Міністрів України «Про внесення змін до постанови Кабінету Міністрів України від 19 травня 1999 р. № 859 та додатку 3 до Типової фрорми договору про медичне обслуговування населення за програмою медичних гарантій» [6]. Даним проектом Постанови пропонується уточнити категорію працівника основної професії, від якої проводитиметься розрахунок посадового окладу керівника та дозволить визначити єдиний підхід до визначення розміру заробітної плати керівника закладу охорони здоров'я: «1ํ. У закладах охорони здоров'я працівником основної професії $€$ посада лікаря». Далі конкретизується механізм розрахунку вихідного посадового окладу керівника: «12. Розмір посадового окладу керівника закладу охорони здоров'я забезпечує співвідношення між середньою заробітною платою медичних працівників та не може перевищувати розмір середньої заробітної плати медичних працівників підприємства більше ніж на 60 відсотків».

Виходячи із даних пропозицій, зробимо спробу спрогнозувати заробітну плату керівника закладу охорони здоров'я. Екс-міністр охорони здоров'я України Максим Степанов 15 грудня 2020 р. заявив, що середня заробітна плата лікаря становить приблизно 9 тис. грн - 3 неї і будемо проводити розрахунки [7]. Отож, якщо розмір посадового окладу керівника закладу охорони здоров'я не може перевищувати розмір середньої заробітної плати медичних працівників підприємства більше ніж на 60 відсотків, то він становитиме $9000+5400=14400$ грн. Це значно менше, аніж 10 окладів молодшого медичного персоналу. Але систему виплати премій, яка закладена у Постанові Кабінету Міністрів України, ніхто не рефрормує. Отож, застосувавши нарахування премій та доплат на новий посадовий оклад за старою схемою, отримаємо річний до- 
хід керівника у сумі 777600 грн (64 800 грн/міс.). Як бачимо, сума значно менша від попередніх варіантів, але «справедливе співвідношення між заробітними платами медичного персоналу та керівного складу закладів охорони здоров'я» досить умовне - різниця між отриманою заробітною платою керівника та лікаря більша як у 7 разів, все-таки в бік керівника.

Варто зазначити, що розрахунки ми проводили без урахування належного оподаткування, яке є стандартним й нічим не відрізняється від звичайних працівників - після сплати податків дані суми зменшаться приблизно на $20 \%$.

У липні 2021 р. був виданий Указ Президента України № 369/2021 Про рішення Ради національної безпеки і оборони України від 30 липня 2021 р. «Про стан національної системи охорони здоров'я та невідкладні заходи щодо забезпечення громадян України медичною допомогою» [4], у якому закладається запровадження ключових показників ефективності для керівників закладів охорони здоров'я державної та комунальної форм власності.

Саме ці показники і могли б лягти в основу оплати роботи керівника закладу охорони здоров'я - КНП, але в проекті жодного слова про це немає. Тому маємо ситуацію, коли заробітна плата керівника виражено дисбалансує 3 оплатою медпрацівників, але не залежить від якості його роботи. Проект змін орієнтований просто на зменшення суми отриманих доходів керівниками і не більше. Якщо даний законопроект буде прийнятий, то і надалі ніякі мотивуючі до ефективної роботи чинники не враховуватимуться і головна мотивація керівника буде орієнтована на утримання у даному кріслі. А головне фрункціональне завдання керівника закладу охорони здоров'я полягає у тому, щоб забезпечити неухильний розвиток закладу шляхом надання високоякісних медичних послуг, використовуючи при цьому мінімальні витрати ресурсів та запроваджуючи інновації науково-технічного прогресу. Налагодження позитивного морально-психологічного клімату та стабільного соціального розвитку колективу, покращуючи умови праці та дбаючи про професійне зростання працівників, керівник значно знизить напруження нерівності в оплаті праці.

В інших країнах питання різкого розшарування оплати праці керівників та працівників стоїть лише у газодобувній сорері, де амплітуда сягає сотень разів. У сорері медичної допомоги різкої різниці між оплатою праці лікарів та менеджерів немає. Більше стоїть питання про різницю в оплаті праці вузьких спеціалістів та сімейних лікарів. У країнах Європи вигода на стороні всетаки вузьких спеціалістів (рис. 1).

Як бачимо, найбільша різниця - в три рази характерна для Бельгії. У два рази різняться їх доходи в Нідерландах. Однак варто відзначити, що у даних країнах середня заробітна плата значно нижча, ніж у медичних працівників.
200

220

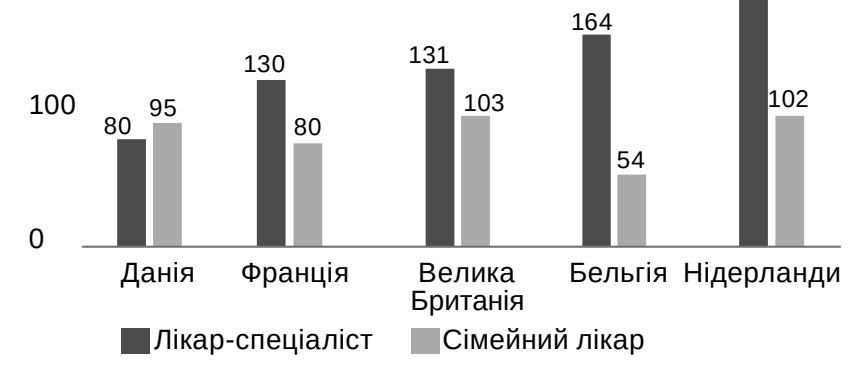

Puc. 1. Середньорічна заробітна плата (тис. євро) лікарів-спеціалістів та сімейних лікарів у деяких країнах Європи у 2015 р.

У Франції лікар отримує в державному госпіталі 4,5-5 тис. євро. Лікар загальної практики (сімейний) може отримувати 6-7 тис. на місяць. Якщо лікар має хірургічну спеціальність і працює в приватній клініці - 7-8 тис. Менеджер середньої ланки медичного закладу: 2,7-3,2 тис. євро на місяць. Директор будинку перестарілих на 120 місць - 4,5 тис. євро на місяць. Директор великого госпіталю, де 10 тис. працівників, отримує 8-10 тис. євро на місяць. Але потрібно знати, що, окрім регулярного оподаткування, в кінці року вони сплачують значний податок: десь близько однієї місячної заробітної плати.

У державних закладах охорони здоров'я Франції виділяють 8 ешелонів менеджерів, заробітні плати яких відрізняються за коефіцієнтами та стажем роботи, і їх зарплата зростає кожні два роки (рис. 2).

\begin{tabular}{|c|c|c|c|c|}
\hline \multicolumn{3}{|c|}{$\begin{array}{l}\text { Directeur des soins-DS } \\
\text { vérifié le } 21 / 08 / 2021\end{array}$} & \multicolumn{2}{|c|}{ Directeur des soins hors classe } \\
\hline Echelon & Indice Brut & Indice majoré & Durée & Salaire brut \\
\hline 1 & 723 & 598 & 2 ans & $2802,24 \epsilon$ \\
\hline 2 & 772 & 635 & 2 ans & $2975,63 €$ \\
\hline 3 & 812 & 666 & 2 ans & $3120,89 \epsilon$ \\
\hline 4 & 861 & 704 & 2 ans & $3298,96 €$ \\
\hline 5 & 906 & 738 & 2 ans & $3458,29 \in$ \\
\hline 6 & 958 & 776 & 3 ans & $3636,36 €$ \\
\hline 7 & 995 & 806 & 3 ans & $3776,94 €$ \\
\hline 8 & 1027 & 830 & - & $3889,40 €$ \\
\hline
\end{tabular}

Malgré tous nos efforts pour mettre à jour ces grilles avec les derniers décrets, une erreur peut toujours s'être glissée. Merci de nous la signaler dans ce cas

\section{Рис. 2. Розподіл заробітної плати у державних} закладах охорони здоров'я Франції.

Тож бачимо, що у Франції конфронтації між зарплатами спеціалістів та менеджерів немає... [7].

\section{Висновки}

Система визначення оплати роботи керівника закладу охорони здоров'я на даний час сорормована за аналогією оплати праці керівників державних підприємств. Мотивація такого підходу була забезпечити керівника так, щоб у нього не було спокуси використовувати активи даного підприємства на свою користь, не брати участь у корупційних схемах, а маючи зарплатню, яка наближається до рівня приватних структур, він мав би дбати про аналогічний розвиток ввіре- 
ного йому підприємства. Але практика показує хибність такого підходу. Державні підприємства у своїй більшості «хиріють», незважаючи на шалені доходи їх керівників. Що ж стосується закладів охорони здоров'я - то тут аналогічний ринковим структурам підхід є антигуманним, а часом і злочинним. Заклади охорони здоров'я не можуть апріорі ґрунтуватися на зростанні доходів за рахунок продажу медичних послуг. Такий «бізнес» $\epsilon$ злочинним і безперспективним у духовному розвитку. Тому і мотивація праці керівників не може ґрунтуватися на матеріальних стимулах збільшення збуту продукції. Якість надання медичної допомоги, яка оговорена стандартами лікування, $\epsilon$, певною мірою, фріксованою і ніяк не може зрос- тати через міфрічні прибутки. Найвища якість медичного працівника - це здоровий пацієнт. Тому в черговий раз хотілося б зазначити, що лікарю необхідно платити не за роботу, а за здорового пацієнта. Стимулами до оплати в медицині повинна бути не хвороба, а здоров'я. Тому і підходи до оплати праці медичних працівників, у тому числі й керівників галузі, мають виходити із пріоритету здоров'я.

Перспективи подальших досліджень полягають у розробці найоптимальніших напрямів формування заробітної плати керівників системи охорони здоров'я за умов постійних трансорормаційних змін.

\section{Список літератури}

1. Автономізація закладів охорони здоров'я [Електронний ресурс]. - Режим доступу : https://healthreform.in.ua/ autonomization/.

2. Зарубіжний досвід нарахування заробітних плат в основних секторах економіки (деякі країни західної та східної Європи) [Електронний ресурс]. - Режим доступу : https://feao.org.ua/wp-content/uploads/2018/08/18_07_31_ economicsectors_v1.8.pdf.

3. Про оплату праці : Закон України [Електронний ресурс]. - Режим доступу : https://zakon.rada.gov.ua/laws/ show/108/95-\%D0\%B2\%D1\%80\#Text.

4. Про рішення Ради національної безпеки і оборони України від 30 липня 2021 року «Про стан національної системи охорони здоров'я та невідкладні заходи щодо забезпечення громадян України медичною допомогою» : Указ Президента України № 369/2021 [Електронний ресурс]. - Режим доступу : https://www.president.gov.ua/ documents/3692021-39713.

5. Про умови і розміри оплати праці керівників підприємств, заснованих на державній, комунальній власності, та об'єднань державних підприємств : Постанова КМУ від 19.05.1999 р. № 859 [Електронний ресурс]. - Режим доступу : https://zakon.rada.gov.ua/laws/show/859-99-\%D0\%BF\#Text.

6. Проект МОЗ «Про внесення змін до Постанови КМУ «Про умови і розміри оплати праці керівників підприємств, заснованих на державній, комунальній власності, та об'єднань державних підприємств» № 859 від 19.05.1999 р.» [Електронний ресурс]. - Режим доступу : https://moz.gov.ua/uploads/ckeditor/\%D0\%93\%D1\%80 \%D0\%BE\%D0\%BC\%D0\%B0\%D0\%B4\%D1\%81\%D1\%8C\%D0\%BA\%D0\%B5\%20\%D0\%BE\%D0\%B1\%D0\%B3\%D0 \%BE\%D0\%B2\%D0\%BE\%D1\%80\%D0\%B5\%D0\%BD\%D0\%BD\%D1\%8F/2021/09/27/1\%D0\%BF\%D1\%80\%D0\%BE \%D0\%B5\%D0\%BA\%D1\%82\%20\%D0\%BF\%D0\%BE\%D1\%81\%D1\%82\%D0\%B0\%D0\%BD\%D0\%BE\%D0\%B2\%D0 \%B8\%20\%D0\%B7\%D0\%BC\%D1\%96\%D0\%BD\%D0\%B8\%20\%D1\%83\%20\%D0\%BF\%D0\%BC\%D1\%83\%20859\%20 \%D1\%82\%D0\%B0\%20\%D1\%84\%D0\%BE\%D1\%80\%D0\%BC\%D0\%B8\%20\%D0\%B4\%D0\%BE\%D0\%B3\%D0\%BE\%D0 \%B2\%D0\%BE\%D1\%80\%D1\%83\%20(1).pdf.

7. Степанов М. Це сором, коли зарплати медпрацівників дорівнюють виплатам по безробіттю [Електронний ресурс] / М. Степанов. - Режим доступу : https://moz.gov.ua/article/news/maksim-stepanov-ce-sorom-koli-zarplatimedpracivnikiv-dorivnjujut-viplatam-po-bezrobittju.

8. У державних закладах охорони здоров'я Франції виділяють 8 ешелонів менеджерів [Електронний ресурс]. Режим доступу : https://www.ehesp.fr/formation/formations-fonction-publique/directeur-des-soins/.

\section{References}

1. Avtonomizatsiya zakladiv okhorony zdorovya [Autonomization of health care institutions]. Retrieved from: https:// healthreform.in.ua/autonomization/

2. (2018). Zarubizhnyy dosvid narakhuvannya zarobitnykh plat $v$ osnovnykh sektorakh ekonomiky (deyaki krayiny zakhidnoyi ta skhidnoyi Yevropy) [Foreign experience in calculating wages in major sectors of the economy (some countries of Western and Eastern Europe)]. Retrieved from: https://feao.org.ua/wp-content/uploads/2018/08/18_07_31_ economicsectors v1.8.pdf

3. (2021). Zakon Ukrayiny «Pro oplatu pratsi» [Law of Ukraine "On Remuneration of Labor"]. zakon.rada.gov.ua. Retrieved from: https://zakon.rada.gov.ua/laws/show/108/95-\%D0\%B2\%D1\%80\#Text

4. (2021). Ukaz Prezydenta Ukrayiny №369/2021 Pro rishennya Rady natsionalnoyi bezpeky i oborony Ukrayiny vid 30 lypnya 2021 roku «Pro stan natsionalnoyi systemy okhorony zdorovya ta nevidkladni zakhody shchodo zabezpechennya hromadyan Ukrayiny medychnoyu dopomohoyu» [Decree of the President of Ukraine No. 369 / 2021 On the decision of the National Security and Defense Council of Ukraine of July 30, 2021 "On the state of the national health care system and urgent measures to provide Ukrainian citizens with medical care"]. www.president.gov.ua. Retrieved from: https://www. president.gov.ua/documents/3692021-39713 
5. (1999). Postanova KMU «Pro umovy i rozmiry oplaty pratsi kerivnykiv pidpryyemstv, zasnovanykh na derzhavniy, komunalniy vlasnosti, ta obyednan derzhavnykh pidpryyemstv» № 859 vid 19.05.1999 [Resolution of the Cabinet of Ministers "On the conditions and amounts of remuneration of managers of enterprises based on state, communal property, and associations of state enterprises" No. 859 from 19.05.1999]. zakon.rada.gov.ua. Retrieved from: https://zakon.rada. gov.ua/laws/show/859-99-\%D0\%BF\#Text

6. (2021). Proyekt MOZ «Pro vnesennya zmin do Postanovy KMU «Pro umovy i rozmiry oplaty pratsi kerivnykiv pidpryyemstv, zasnovanykh na derzhavniy, komunalniy vlasnosti, ta obyednan derzhavnykh pidpryyemstv» № 859 vid 19.05.1999» [Project of the Ministry of Health "On Amendments to the Resolution of the Cabinet of Ministers" On the conditions and amounts of remuneration of managers of enterprises based on state, municipal property, and associations of state enterprises "No. 859 from 19.05.1999"]. moz.gov.ua. Retrieved from: https://moz.gov.ua/uploads/ckeditor/\%D0\%9 3\%D1\%80\%D0\%BE\%D0\%BC\%D0\%B0\%D0\%B4\%D1\%81\%D1\%8C\%D0\%BA\%D0\%B5\%20\%D0\%BE\%D0\%B1\%D0\% B3\%D0\%BE\%D0\%B2\%D0\%BE\%D1\%80\%D0\%B5\%D0\%BD\%D0\%BD\%D1\%8F/2021/09/27/1\%D0\%BF\%D1\%80\%D0 \%BE\%D0\%B5\%D0\%BA\%D1\%82\%20\%D0\%BF\%D0\%BE\%D1\%81\%D1\%82\%D0\%B0\%D0\%BD\%D0\%BE\%D0\%B2\%D 0\%B8\%20\%D0\%B7\%D0\%BC\%D1\%96\%D0\%BD\%D0\%B8\%20\%D1\%83\%20\%D0\%BF\%D0\%BC\%D1\%83\%20859\%20 \%D1\%82\%D0\%B0\%20\%D1\%84\%D0\%BE\%D1\%80\%D0\%BC\%D0\%B8\%20\%D0\%B4\%D0\%BE\%D0\%B3\%D0\%BE\%D0 \%B2\%D0\%BE\%D1\%80\%D1\%83\%20(1).pdf

7. (2020). Stepanov Maksym Tse sorom, koly zarplaty medpratsivnykiv dorivnyuyut vyplatam po bezrobittyu [It is a shame when the salaries of medical workers are equal to unemployment benefits]. moz.gov.ua. Retrieved from: https://moz.gov. ua/article/news/maksim-stepanov-ce-sorom-koli-zarplati-medpracivnikiv-dorivnjujut-viplatam-po-bezrobittju

8. U derzhavnykh zakladakh okhorony zdorovya Frantsiyi vydilyayut 8 esheloniv menedzheriv [In public health care facilities in France there are 8 echelons of managers]. Retrieved from: https://www.ehesp.fr/formation/formations-fonctionpublique/directeur-des-soins/

\section{ON THE ISSUE OF SALARIES OF HEALTHCARE MANAGERS}

O. N. Lytvynova, L. V. Lishtaba

I. Horbachevsky Ternopil National Medical University, Ternopil, Ukraine

Purpose: to substantiate the conceptual directions of salary formation of health care managers.

Materials and methods. To achieve this goal, the work used general scientific methods of analysis, synthesis, generalization, interpretation of scientific data, as well as systemic and structural-functional approaches.

Results. Conceptual directions of salary formation of health care system managers are substantiated taking into account the system approach, the Constitution of Ukraine, laws and other normative legal acts of Ukraine, generally accepted principles and norms of international law in the field of health care, domestic and foreign experience. Conceptual directions form a new system of salary formation on the principles of public-private partnership, provide a stable economic situation and the possibility of developing the base of the medical institution.

Conclusions. The development of conceptual directions for the formation of salaries of health care managers will optimize the work of the medical institution and ensure the steady development of the institution by providing high quality medical services, using minimal resource costs and introducing innovations in scientific and technological progress.

KEY WORDS: salary; health care system; health care manager; wage.

Рукопис надійшов до редакції 09.09.2021 p.

\section{Відомості про авторів:}

Литвинова Ольга Несторівна - кандидат медичних наук, доцент кафедри громадського здоров'я та управління охороною здоров'я Тернопільського національного медичного університету імені І. Я. Горбачевського МОЗ України; тел.: +38(0352) 52-72-33.

Ліштаба Людмила Вікторівна - кандидат економічних наук, доцент кафедри громадського здоров'я та управління охороною здоров'я Тернопільського національного медичного університету імені І. Я. Горбачевського МОЗ України; тел.: +38(0352) 52-72-33. 